\title{
K HISTORICKÝM ZDROJOM LIBERALIZMU - MEDZI POLITICKOU IDEOLÓGIOU A FILOZOFICKÝMI POJMAMI
}

JAKUB ŠVEC, Katedra filozofie Filozofickej fakulty Univerzity Mateja Bela v Banskej Bystrici, Banská Bystrica, SR

ŠVEC, J.: On Historical Sources of Liberalism - Between Political Ideology and Philosophical Concepts

FILOZOFIA, 75, 2020, No 5, pp. $341-355$

The ideology of liberalism is not a closed intellectual space where inspiration can no longer be found. Based on a comparison of three philosophers - Thomas Hobbes, John Locke, Jean-Jacques Rousseau, and their approaches to the key concepts of freedom, autonomy and property, the article explains the context of the historical evolution of liberalism in its early stages. The aim of the article is to show that liberalism does not have just one understanding of these concepts. In the context of this statement, we consider it as necessary to reconsider the traditional view of liberalism as an ideology that promotes laissez-faire policy and does not seek to actively counter social inequalities or to some extent interfere with the freedom and property rights of individuals.

Keywords: Liberalism - Thomas Hobbes - Jean-Jacques Rousseau - DespotismContractualism

\section{Úvod}

Stat' sa zameriava na filozofický výklad postojov troch predstavitel’ov ranného liberalizmu k vybraným pojmom a skúma rozdiely a prieniky medzi zmluvnými teóriami, ktoré navrhujú vo svojich dielach. V texte na tieto momenty poukazujeme prostredníctvom komparácie pojmov slobody, autonómie a vlastníctva, so zretel’om na fikciu prirodzeného stavu. Fikcia prirodzeného stavu v zmluvných teóriách jednotlivých autorov je nástrojom pre kvalitatívne a obsahové porovnanie daných pojmov. $\mathrm{Z}$ tejto komparácie vyplývajú výrazné odlišnosti napriek faktu, že traja filozofi (Thomas Hobbes, John Locke, Jean-Jacques Rousseau) zhodne vychádzajú z rovnakej motivácie - neobmedzenej individuality v prirodzenom stave. $\mathrm{V}$ stati chceme argumentovat', že téza o jednotnom koncepte tak anglosaského, ako aj kontinentálneho liberalizmu, spätá s nedotknutel'nost'ou vlastníctva a úlohou štátu len ako nočného strážnika, nie je adekvátna. V texte sa zameriame len na filozofickú interpretáciu liberalizmu 
v opozícií voči politickému a ekonomickému výkladu. Zohl'adňujeme však aj začlenenie liberalizmu do širších historicko-spoločenských súvislostí. Náš záujem o túto tému vyplýva zo snahy oddelit’ filozofické aspekty liberalizmu od tých myšlienok, ktoré intelektuálne motivovali ideológiu liberalizmu.

Diskusia o historickom vývoji liberalizmu a vzájomnom vzt’ahu slobody, autonómie a vlastníctva je zaujímavá aj z hladiska súčasného filozoficko-politického diskurzu. Vo svetle ideologického súboja sa predmetné pojmy objavujú v polemikách a diskusiách často, predovšetkým v intencii ich ochrany. Stat' chce preukázat', že liberalizmus nedisponuje jednotným pohl'adom na uvedené pojmy. Odvolávat' sa na jednoduchú ochranu slobody preto môže v praxi pôsobit' zmätočne. Filozofický aj politický pohl’ad v rámci liberalizmu totiž berie do úvahy viaceré názory na slobodu, autonómiu, ale aj na vlastníctvo. V čase, ked' sa dôraz kladie na občianske slobody spojené s negatívnou slobodou, vlastníctvom a autonómiou, pokladáme za dôležité analyzovat' práve tieto koncepty aj $\mathrm{v}$ dielach klasikov liberalizmu.

\section{Prirodzený stav vo svetle ranného liberalizmu}

S fikciou prirodzeného stavu pracujú všetky koncepcie zmienených autorov. Fiktívny priestor slúži pre náčrt hypotetických modelov správania jednotlivcov v prostredí neexistencie autority a politickej spoločnosti. Každý z predmetných filozofov však vníma okolnosti fiktívneho stavu odlišne. Hoci u autorov existuje zhoda o základných charakteristikách prirodzeného stavu, teda neexistencia politickej spoločnosti a autority a absolútna sloboda jednotlivca, v jeho kvalitatívnom hodnotení sa zásadne rozchádzajú.

Hobbes reprezentuje $\mathrm{v}$ rannom novoveku prístup konfrontujúci neželaný stav anarchie prostredníctvom návrhu zriadenia, ktoré nečerpá legitimitu od Boha, ale zo záujmov jednotlivcov. Ako protagonista kontraktualizmu ponúka zmluvnú koncepciu ustanovenia politického spoločenstva na základe súhlasu zúčastnených indivíduí v prirodzenom stave. „O štáte sa hovorí ako o ustanovenom vtedy, ked’ sa vel'ký počet l'udí dohodne a každý s každým uzavrie zmluvu (...) Z takého ustanovenia štátu sa odovzdajú všetky práva a moc tomu alebo tým, na ktorých bola so súhlasom zhromaždeného l'udu prenesená suverénna moc“ (Hobbes 2011, 211). Prirodzený stav vníma ako priestor absolútnej slobody, ked’ jednotlivec môže konat' podl’a vlastného uváženia. Ide o stav permanentnej vojny, ustavičného napätia a neistoty, nakol'ko v prípade pocitu ohrozenia vlastného života má jednotlivec právo siahnut na život druhého, odvolávajúc sa na prirodzené právo (ius naturale): „Je (to) sloboda každého človeka používat' svoju vlastnú moc, ako sám chce, na zachovanie svojej vlastnej prirodzenosti, to znamená svojho vlastného života“ (Hobbes 2011, 167). Takémuto konaniu má však predchádzat' prirodzený zákon (lex naturalis), ktorý 
Hobbes charakterizuje ako: „Všeobecné pravidlo objavené rozumom, ktoré človeku zakazuje konat' to, čo ničí jeho život alebo ho zbavuje prostriedkov nevyhnutných na jeho zachovanie“ (Hobbes 2011, 167). Autor nepokladá ludské bytosti za automaticky agresívne či bažiace po vojne. Naopak, u jednotlivcov predpokladá skôr snahu o mierové spolunažívanie. I ked' prirodzené právo hovorí o možnosti bránit' sa $\mathrm{v}$ prípade konfliktu, takémuto stavu má predchádzat' snaha o zachovanie mieru. Konflikty filozof nepovažuje za prejav l'udskej podstaty, ale skôr za prejav obavy z toho, že ostatní nebudú prirodzený zákon v prirodzenom stave dodržiavat'. Vojna je v Hobbesovej filozofii označovaná za neznesitel'ný stav, pričom prirodzený zákon jednotlivcom prikazuje hl'adat' východiská z takejto situácie. Autor sa domnieva, že pri vol'be medzi dvoma možnost’ami správania voči sebe - agresiou a kooperáciou - jednotlivci zvolia druhú možnost', čo je i v súlade s prirodzeným zákonom. Ak sa navyše jednotlivci dohodnú na spolupráci a trestaní agresie prostredníctvom zákona, dospejú k spoločenskej zmluve, ktorá má vyviest' l'udstvo z okov prirodzeného stavu.

Rovnako ako Locke a Rousseau i Hobbes vidí v zmluve riešenie tejto situácie - štát má fungovat' na základe dohody medzi všetkými jednotlivcami, a to vzdaním sa prirodzeného práva, ktoré bude prenesené na suveréna. „Práva sa niekto vzdáva bud' jednoduchým zrieknutím, alebo prevodom na druhého (...) A ked' niekto opustil alebo udelil svoje právo, potom sa hovorí, že je povinný alebo viazaný neprekážat' v prospechu tomu, komu právo udelil alebo prenechal“ (Hobbes 2011, 169). A síce suverénom môže byt' viacero osôb, Hobbes sa zmieňuje o ideálnom stave, ked' je suverénom práve jeden jednotlivec, ktorý sa zodpovedá len Bohu a je zdrojom práva. $\mathrm{V}$ jedenástom bode Leviatana, $\mathrm{v}$ kapitole venujúcej sa právam ustanovených suverénom autor hovorí o právomociach odmeňovat' - bohatstvom a poctami -, a naopak trestat' - finančnými aj fyzickými trestami alebo postihom na cti (Hobbes, 2011). Neskôr v kapitole $O$ trestoch a odmenách filozof predkladá v niekol'kých bodoch dôvody možnej perzekúcie. Trest pokladá za prostriedok na naklonenie l'udskej vôle k poslušnosti. Taktiež určuje, kto môže prehrešok posudzovat' a určovat' trest, a následne uvádza rôzne druhy postihov, od peňažných pokút až po popravu. Vzniká tak paradoxná situácia, ked' sa autor zastáva absolutizmu, voči ktorému sa Locke či Rousseau usilovali vymedzit'. Prenesením prirodzeného práva na suveréna vzniká v hobbesovskej filozofii štát, respektíve vel'ký Leviatan, takzvaný smrtelný Boh, ktorému jednotlivci vd'ačia za mier a ochranu.

V kontraste s teóriou Hobbesa vo filozofii Locka štát nezohráva len úlohu ochrany mieru, ale vystupuje aj ako garant l'udských práv (Laukötter 2017,34). Postoj filozofa k spomenutým pojmom slobody, autonómie a vlastníctva sa, identicky ako u Hobbesa, najzretel’nejšie kryštalizuje v priestore prirodzeného stavu. Tento fiktívny 
priestor, označovaný autorom aj ako král’ovský, považuje za predpolitický, pričom človek sa v ňom ocitá ako produkt Boha - stvoritel’a a vlastníka všetkého (Manda 2013, 239). Predstavuje prostredie absolútnej slobody jednotlivca, v ktorom sú si l'udia dokonale rovní. „Je to stav dokonalej slobody riadit' svoje konanie a nakladat' so svojím majetkom a osobou tak, ako jednotlivec uzná za vhodné v medziach prirodzeného zákona bez toho, aby žiadal povolenie od iného, alebo aby jeho konanie záviselo od vôle kohokol'vek iného“ (Locke 1992, 30). Stav vojny je, rovnako ako v prípade Hobbesa, v prirodzenom stave prípustný, no nie nevyhnutný. Vzniká narušením prirodzeného poriadku jednotlivcom, ktorý takýmto činom stráca ochranu prirodzeného zákona a ostatným otvára dvere $\mathrm{k}$ odvete a potrestaniu. ${ }^{1}$ „Prirodzený stav má prirodzený zákon pre svoje riadenie, ktorý zaväzuje každého a rozum, ktorým je tento zákon, učí celé l'udstvo (...), že všetci sú si rovní a nezávislí (a) nikto nemá poškodzovat' druhého v jeho živote, zdraví, slobode a majetku“ (Locke 1992, 32). Moc využívat' prirodzený zákon vkladá autor do rúk všetkých s ciel'om umožnit' jednotlivcom zabraňovat' jeho porušovaniu.

So zretel'om na postoj Hobbesa k prirodzenému zákonu treba dodat', že Locke vo svojom diele Druhé pojednanie o vláde, konkrétne v siedmej kapitole $O$ politickej, čiže občianskej spoločnosti doplńa, že právo uplatňovat' trest pre vinníka podlieha kritériu adekvátnosti a miery (Locke1992, 79 - 80). Prirodzený zákon v priestore prirodzeného stavu hovorí, že: „Každé prekročenie (prirodzeného zákona) smie byt' potrestané $\mathrm{v}$ tom stupni a takou prísnostou, ktorá postačí $\mathrm{k}$ tomu, aby $\mathrm{z}$ neho (trestu) učinili zlý príklad pre vinníka, dali mu podnet $\mathrm{k}$ lútosti a odstrašili iných od podobných činov" (Locke 1992, 35).

Východiskom z tejto nestálej podoby koexistencie je, rovnako ako v prípade T. Hobbesa, kontraktualizmus. K transformácii z predpolitického prirodzeného stavu do stavu ustálenej politickej a občianskej spoločnosti je nutný súhlas všetkých jednotlivcov, zúčastňujúcich sa na koncipovaní zmluvy. „Kdekol'vek sa teda nejaký počet l'udí spojí v jednu spoločnost', kedy sa každý vzdá svojej výkonnej moci prirodzeného práva a odstúpi ju verejnosti, tam a jedine tam existuje politická, čiže občianska spoločnost' (...) A toto privádza l'udí zo stavu prirodzeného do stavu štátu tým, že dosadzuje sudcov na zemi s oprávnením rozhodovat' všetky spory a napravovat' bezprávie, ktoré sa môže prihodit' ktorémukol'vek členovi štátu“ (Locke 1992, 80). Na ustanovenie formy vlády autorovi postačuje jednoduchá väčšina. Za najideálnejšiu vládu pokladá konštitučnú monarchiu, ktorá je obmedzovaná a kontrolovaná systémom jednotlivých zložiek moci.

\footnotetext{
${ }^{1}$ Prirodzený zákon: Zachovaj seba, neškod’ druhým.
} 
Podobne ako sa Locke inšpiroval kontraktualizmom Hobbesa, francúzsky filozof Rousseau bol ovplyvnený práve závermi spomínaného otca liberalizmu Locka. Rousseau, rovnako ako Locke a Hobbes, pracuje s myšlienkou prirodzeného stavu, ktorý však rozvíja inak ako jeho predchodcovia. Pre autora nepredstavuje prirodzený stav prostredie vojny a strachu o svoj život (Hobbes) ani stav nevyhovujúci, ktorý je nutné napravit' spoločenskou zmluvou (Locke). Rousseau hovorí o prirodzenom stave ako o priestore šs'astia a zlatého veku, kde sú l’udia peknými a ušl'achtilými bytost'ami. „Divochove priania nepresahujú jeho telesné potreby (...) jediné zlo, ktoré pozná, je bolest' a hlad“ (Sobotka 2015, 14). Tvrdí, že jednoduchý prírodný človek nemohol byt' zlý ani dobrý, nakol'ko tieto vlastnosti vznikajú až po uzatvorení zmluvy v spoločnosti, pričom o existencii takej zmluvy v prirodzenom stave nemožno hovorit'. „Hobbes tvrdí, že človek je prirodzene neohrozený a priam vyhl’adáva útok a súboj. Iný slávny filozof si naopak myslí, čo potvrdzujú aj Cumberland a Pufendorf, že niet plachejšieho tvora ako človek v prirodzenom stave“ (Rousseau 2010, 45).

Voči tomuto postoju sa Rousseau opätovne vyhraňuje v diele $O$ pôvode a príčinách nerovností medzi l'ud’mi, kde tvrdí: „Najmä sa stráňme tvrdit' v súlade s Hobbesom, že človek je od prírody zlý, lebo si nevie predstavit' dobro, že je skazený, lebo nemá kúska cti, že odopiera pomoc blížnym (...)“ (Rousseau 2010, 60). Priestor prirodzeného stavu filozof opisuje ako prostredie absolútnej slobody a autonómie, kde jednotlivci oplývajú slobodnou vôlou, slobodným konaním a rozhodovaním, sú otvorení k zmenám. Prirodzenost' človeka v takomto stave neexistuje, jednotlivec ju získava až po začlenení do spoločnosti. Človek divoch však disponuje dvoma základnými vlastnost’ami - súcitom a pudom sebazáchovy. Medznou fázou k vzniku spoločnosti je zakladanie rodín, ktoré nakoniec dospeje k záverečnej fáze- vzniku politickej spoločnosti. V nej je však jednotlivec konfrontovaný so vznikom sebectva, sebalásky, prestáva sa zaujímat' o ostatných a $\mathrm{v}$ centre jeho pozornosti je on sám a jeho rodina. Stáva sa rozumovým tvorom. „Poddanské putá sa vytvorili na základe vzájomnej závislosti l'udí a vzájomných potrieb, čo ich zaväzujú (...)“(Rousseau 2010, 69). Autor sa rozchádza s Hobbesom a Lockom, ktorí tvrdia, že človek má prirodzenú tendenciu byt' skôr zlý, a preto je zmluva riešením prirodzeného stavu. Rousseau pokladá tento prevod za skazu pre vznešeného divocha, a to i napriek faktu, že prirodzený stav predstavoval systém nadvlády potenciálneho násilia nad zákonom, podobne ako v prípade teórie Hobbesa. „Človek stráca spoločenskou zmluvou svoju prirodzenú slobodu a neobmedzené právo na všetko, čo ho láka a čo môže dosiahnut'. Získava však občiansku slobodu a vlastníctvo všetkého, čo má“ (Brandt 2017, 45). Zaujímavým momentom je prehodnotenie autorových pôvodných záverov, spojených s prirodzeným stavom. Zatial' čo v diele Rozprava o pôvode a príčinách nerovností medzi l'ud'mi sa filozof zamýšl'a, ako mohlo l'udstvo dopustit' zrušenie prirodzeného stavu a nastolenie 
právneho štátu, v d'alšom významnom diele $O$ spoločenskej zmluve už dohodu nehodnotí výlučne negatívne. $\mathrm{V}$ kontexte zmeny uvažovania o prospešnosti prirodzeného stavu autor reviduje i svoje názory na vlastníctvo a slobodu, ktoré musí prispôsobit' novým podmienkam, v ktorých sa jednotlivec po uzavretí zmluvy ocitol. K tomuto momentu sa ešte dostaneme $v$ nasledujúcom texte.

\section{Vlastníctvo vo filozofii raného liberalizmu}

Pri hodnotení vzt'ahu autorov $\mathrm{k}$ vlastníctvu treba zohl'adňovat' ich vzt'ah $\mathrm{k}$ hodnotám slobody a autonómie. Aj v rámci liberalizmu vzt'ah k vlastníctvu automaticky nepredstavuje neobmedzené možnosti nadobúdania hmotného majetku a jeho následnú ochranu. Diela raných liberálnych myslitel’ov poukazujú na hlbšie úvahy o vlastníctve a jeho povahe, ktoré neredukujú do roviny neobmedzeného vlastnenia materiálnych statkov.

Pojem vlastníctva sa vo filozofii Hobbesa chápe najmä cez prizmu vlastnenia vlastného života $\mathrm{v}$ prirodzenom stave, ale aj v zriadení po ustanovení suveréna. $\mathrm{V}$ prirodzenom stave má každý prirodzené právo používat' plný rozsah vlastnej moci pre ochranu a zachovanie života. „Ked’že každý je oprávnený rozhodovat' o tom, čo musí urobit' pre vlastnú sebazáchovu, prislúcha každému právo na každú vec, dokonca i na telo iného človeka“" (Celikates 2017, 28). Jednotlivec sa dobrovol'ne môže vzdat' časti svojich práv alebo majetku, avšak neprislúcha mu právo vzdat' sa práva na odpor, ked’že takéto konanie odporuje právu na vlastnenie života. Autor nepokladá jednotlivcov za prirodzene spoločenských, pretože všetci hl'adajú prospech a čest' (uznanie), vytvárajú medzi sebou účelové väzby, do ktorých vstupujú spravidla v záujme dosiahnutia bezpečia, uznania a materiálneho uspokojenia, ktoré jednotlivcovi zabezpečujú dôstojnost'. Problematika v autorovej filozofii sa vzt'ahuje na prípadné rozdelenie bohatstva: „Ved’ toho, o čo každému ide, nie je tol'ko, aby sa na každého dostalo v miere, ktorú považuje za adekvátnu. L'udia sa usilujú o bohatstvo, bezpečnost', o slávu“ (Novosád 2013, 224). Podl'a Hobbesa navyše neexistuje žiadny osobitý dôvod na rozdel'ovanie bohatstva a bezpečnosti, pretože: „Najbezpečnejšie sa môžem cítit' vtedy, ked' viem, že všetci ostatní sú bezmocní, že nič voči mne nezmôžu“ (Novosád 2013, 224). Autor uvažuje o jednotlivcoch ako o racionálnych egoistoch konfrontovaných so situáciou nedostatku, ktorí sa usilujú pravidlá spolužitia koncipovat' tak, aby prevažovali tie, v ktorých indivíduum získava (Novosád 2013. 224).

Locke vníma liberalizmus predovšetkým prostredníctvom ekonomickej teórie tejto ideológie a vzhl'adom $\mathrm{k}$ tomu prezentuje svoj vzt'ah voči vlastníctvu odlišne ako Hobbes. „Aby človek mohol naplnit’ uvedený príkaz prirodzeného zákona, musí mat' možnost' prisvojovat' si predmety sveta. Preto Boh daroval zem a jej produkty l'udstvu spoločne“ (Manda 2013, 239). Filozof predpokladá v túžbe jednotlivca 
vlastnit' klúčový prvok prirodzeného stavu, ktorý je zároveň východiskom z tejto situácie, a zúčastnených donúti ku koncipovaniu dohody, pretože jednotlivci sa v predpolitickom stave zhodnú na potrebe ochrany majetku autoritou. Právo na vlastníctvo spája s povinnost'ou uchovat' svoj život. „Hlavným zmyslom kapitoly o vlastníctve je podl’a Locka ukázat', ako z vecí daných človeku spoločne mohlo vzniknút' súkromné vlastníctvo človeka, vylučujúce vlastníctvo iných indivíduí“ (Manda 2013, 239). Locke nahliada na vlastníctvo v dvoch rovinách. Prirodzené - obsahuje predmety s krátkou dobou trvanlivosti, ktoré sú nevyhnutné pre prežitie, a neprirodzené či peňažné, ktoré zahíňa vlastníctvo drahých kovov a peňazí. Prioritnou motiváciou autora je objasnit' a obhájit' možnost' transformácie spoločného vlastníctva na vlastníctvo súkromné.

O súkromnom vlastníctve sa Locke zmieňuje $\mathrm{v}$ troch rovinách jeho vývinu. Prvá rovina predstavuje limitované vlastníctvo všetkých prírodných zdrojov, ktoré dal l'ud’om Boh na uchovanie života a vlastníctva seba samého. Spojením telesnej aktivity a prírodných zdrojov vznikajú predmety, ktoré jednotlivcovi patria v súlade $\mathrm{s}$ teóriou užívania - tá hovorí o možnosti vlastnit' predmety na bezprostrednú spotrebu, no len do miery, do ktorej je to potrebné na aktívne užívanie. „Ten, kto sa živí žalud’mi, ktoré nazbieral pod dubom, alebo jablkami, ktoré natrhal na stromoch $\mathrm{v}$ lese, si ich iste privlastnil. Nik nemôže popriet', že táto potrava je jeho. Pýtam sa teda, kedy začala byt' jeho? (...) Je jasné, že ak ju prvé nazbieranie neurčilo za jeho potravu, nič iné to učinit' nemohlo“(Locke 1992, 45). Vlastnenie predmetov, ktoré jednotlivec vytvára prácou, no nie na bezprostrednú spotrebu, ale aj pre následný obchod, je povolené. Podmienkou ostáva nutnost' neznehodnotenia majetku jeho aktívnym neužívaním.

Druhú rovinu predstavuje výmenné súkromné vlastníctvo. „Základom výmenného vlastníctva nie je práca uspokojujúca potreby, ale výmena nadbytku za všeobecný predmet, teda za peniaze“ (Manda 2013, 244), pričom autor neustupuje z podmienky predat' produkty ešte predtým, než by sa znehodnotili. „A keby chcel dat' svoje orechy za kus kovu, ktorého farba sa mu páčila, alebo vymenit' svoje ovocie za lastúry alebo vlnu za lesklé oblázky alebo za diamant a podržat' ich u seba po celý svoj život, neporušil právo iných, mohol nakúpit' tol'ko týchto trvalých vecí, kol'ko chcel, pretože prekročenie hraníc jeho spravodlivého vlastníctva nespočívalo v rozsiahlosti jeho majetku, ale v tom, že by sa čokol'vek z neho neužitočne skazilo. A takto sa dostavilo užívanie peňazí, trvalej veci, ktorú l'udia mohli mat' v držbe bez toho, aby sa skazila, a ktorú na základe vzájomného súhlasu prijímali výmenou za užitočné, ale skaze podliehajúce životné potreby“ (Locke 1992, 56 - 57). Tretia rovina predstavuje vlastníctvo legálne - súkromné. V tejto fáze „Možno hovorit’ o tom, že (...) vlastníctvo v štáte nadobúda podobu skutočne legálneho vlastníctva“ (Manda 2015, 77). 
Tretia fáza vlastníctva zapríčiňuje prechod indivíduí z prirodzeného stavu do stavu politického. V tejto časti už jednotlivci nerozhodujú o spôsoboch nadobudnutia majetku, nakol'ko podmienky nadobudnutia sú upravené príslušnými zákonmi schval’ovanými výkonnou mocou. Podla Locka práve súkromné vlastníctvo motivovalo človeka $\mathrm{k}$ zanechaniu prirodzeného stavu a dalo podnet k vzniku dohôd medzi: „Nezávislými, prírodnými, nesociálnymi indivíduami o vzájomnej výmene tovarov, a tým podnietilo vznik a rozvoj vzt'ahov medzi indivíduami, ktoré nakoniec vyústili do jednej všeobecnej dohody o vzniku politickej spoločnosti““ (Manda 2013, 237). Hlavnou podmienkou pre získanie legálneho vlastníctva je úmyselná ciel’avedomá činnost' človeka spojená s prírodou. Autorov pohl'ad na vlastníctvo je silno ovplyvnený ekonomickým náhl'adom na správanie jednotlivca $\mathrm{v}$ spoločnosti.

Výrazne odlišné nazeranie na pojem vlastníctva vo filozofii ponúka Jean-Jacques Rousseau. Predmety sú pre filozofa spoločným vlastníctvom, čím sa jeho teória dostáva do nesúladu so závermi jeho predchodcov. Takýto postoj autora je však v kontexte jeho chápania prirodzeného stavu ako vznešeného prostredia pochopitel'ný. Deklaruje ho v úvode druhej časti $O$ pôvode a prićinách nerovností medzi l'ud'mi slovami: „Majte sa na pozore pred tým podvodníkom, ak ho počúvnete a zabudnete, že plody patria všetkým a pôda nikomu, ste stratení!“ (Rousseau 2010, 71) Podl'a Rousseaua ohradzovanie pozemkov a chránenie majetku l’udí morálne skazilo. Je nesprávne uvažovat' o vláde ako o niečom, čo má predovšetkým chránit' súkromné vlastníctvo. Naopak, úlohou vlády by malo byt' zmierňovanie ekonomických nerovností, pretože občania by si mali byt' rovní ekonomicky aj morálne, a to bez ohl'adu na fyzické atribúty. Politika má obsahovat' diskusie o cnostiach, nie o obchode a peniazoch.

Ako bolo v časti venovanej prirodzenému stavu naznačené, človek stráca spoločenskou zmluvou neobmedzené právo na všetko, čo si chce privlastnit', na druhej strane však získava legálne vlastníctvo všetkého, čo nadobudol v súlade s právom. M. Sobotka tvrdí, že tento proces Rousseau označuje ako: „prechod (len) od držby $k$ (spoločnost'ou) uznanému vlastníctvu a od osobných preferencií k právu“" (Sobotka 2015, 39). V tejto deskripcii môžeme opakovane sledovat' paralelu, ktorá sa venuje možnostiam privlastnenia vecí v prirodzenom stave, pričom nadväzuje na Hobbesa. Pojem slobody a vlastníctva je v autorovom diele úzko spätý. Najslobodnejší boli l'udia $\mathrm{v}$ prirodzenom stave práve preto, že neexistovalo súkromné vlastníctvo, jednotlivci mali svoje skromné individuálne potreby. Ako píše M. Sobotka, podla Rousseaua sa osudovým nešt’astím pre l'udstvo stalo súkromné vlastníctvo a vzájomná závislost' l'udí previazaných väzbami (Sobotka 2015, 15). Z týchto väzieb nevyhnutne vzniká spoločenská nerovnost'. Môže sa zdat', že vo filozofii francúzskeho autora dochádza $\mathrm{k}$ eklekticizmu. Jeho negatívny postoj $\mathrm{k}$ vlastníctvu nahrádza $\mathrm{v}$ iných častiach diela Rozpravy o pôvode nerovností medzi l’ud'mi tvrdeniami o vlastníctve ako 
o „najväčšom št'astí, ktoré l’udstvo stretlo “(Sobotka 2012, 10). Napriek znepokojeniu z negatívnych dôsledkov vlastníctva filozof chápe, že tento okamih je nevyhnutným sprievodným javom civilizácie. Pred podobnou dilemou stojí autor pri úvahách o slobode, respektíve o autonómii, ktorej sa jednotlivec musí vzdat' v prospech spoločnosti. $\mathrm{K}$ tomuto momentu sa dostaneme $\mathrm{v}$ časti venovanej slobode a autonómií, pričom vysvetlíme, že napriek zdanlivej nekonzistentnosti sú tieto tvrdenia koherentné.

Ideálny stav sa pre autora končí prvopočiatočným nadobudnutím majetku (pôdy), ktoré predstavuje medzník v procese vzniku civilizovanej spoločnosti. Ako d'alej filozof uvádza, l’udstvo by sa ušetrilo mnohých vojen, vrážd a biedy, keby nezabudlo, že plody patria všetkým a pôda nikomu. Neskôr však Rousseau prehodnocuje i tento postoj a pod tlakom argumentov pripúšt’a, že pomery v kontexte vývoja spoločnosti sa natol'ko zmenili, že l'udstvo nemožno udržat' v podmienkach prirodzeného stavu, a tak nevyhnutne smeruje k vývoju. V druhej časti $O$ pôvode a príčinách nerovností medzi l'ud'mi filozof tento stav vysvetl'uje nasledovne: „S rozvojom ducha sa zdokonal'ovala aj remeselnícka činnost' (...) zanedlho prestal líhat' pod prvý strom (...) vynašiel viacero sekier z tvrdého a ostrého (...) híbil jamy v zemi a staval si chyže. To už dospel do obdobia prvej revolúcie, ktorá rozdel'ovala rodiny, ktorá zahŕňala akýsi druh vlastníctva“ (Rousseau 2010,74). Vyhrotením pomerov má autor na mysli prudký nárast populácie, geopolitické, ekonomické a klimatické faktory, ktoré donútili populáciu prejst' $\mathrm{k}$ sofistikovanejším spôsobom bývania, ochrany, zabezpečovania potravy. Filozof ich v skratke popisuje vývojom pracovných nástrojov, reči, združovaním l’udí do väčších skupín či národov až po del'bu práce, ktorá vyústila vo vlastnícke práva, ktoré sú podl'a filozofa zdrojom spoločenských nerovností.

Tento proces označuje za nežiaduci, no z hl'adiska vývoja spoločnosti nezvratný. „Prvý človek, ktorý si ohradil pozemok, odvážil sa vyhlásit’: Toto je moje! A našiel nadostač prostoduchých l'udí, čo mu uverili, stal sa skutočným zakladatelom civilizovanej spoločnosti“ (Rousseau 2010, 71). Vývoj súkromného vlastníctva je v autorovej filozofii spájaný so vznikom vzájomnej závislosti. L'udské schopnosti ako pamät', predstavivost', samolúbost', rozum a duch sa ocitli na vysokom stupni rozvoja. Rousseau chápe vlastníctvo ako prejav a výsledok vzniku spoločnosti, ktorý je v kontexte vývoja nezvratný a vedie k rozdel’ovaniu l'udí. Vznik vlastníctva $\mathrm{v}$ autorovej filozofii predstavuje jeden $\mathrm{z}$ hlavných míl'nikov prechodu z prirodzeného stavu do stavu ucelenej spoločnosti.

\section{Medzi slobodou a autonómiou}

Témy slobody a autonómie obsahujú v dielach spomenutých autorov (Hobbes, Locke, Rousseau) silné postoje k obhajobe týchto pojmov. Hoci všetci pracujú s myšlienkou neobmedzenej slobody a autonómie jednotlivca v prirodzenom stave, po ustanovení 
zmluvy rozvíjajú svoje koncepcie odlišne. Filozofia Hobbesa je prísne individualistická, pričom stavebným prvkom spoločnosti je podl'a neho indivíduum, ktoré je schopné samostatne si určovat' vlastné ciele. „Príroda vytvorila l'udí natol'ko seberovných v schopnostiach tela a mysle, že hoci sa občas nájde bystrejší než druhý (...) nie je tento rozdiel taký závažný“ (Hobbes 2011, 161). Filozof svojím dielom prelomil klasické aristotelovské chápanie vzt'ahu medzi štátom a jednotlivcom, podl’a ktorého je štát prirodzenejšou formou spoločenstva ako rodina (Novosád 2013, 223). Najvyšší stupeň autonómie a slobody môže jednotlivec užívat' v prostredí prirodzeného stavu využívaním ius naturale (prirodzeného práva). To v najobecnejšom zmysle slova vyjadruje: „Slobodu každého človeka používat' svoju vlastnú moc, ako sám chce, na zachovanie svojej vlastnej prirodzenosti, tzn. vlastného života, a teda na konanie všetkého, čo podla vlastného úsudku a rozumu považuje za najvýhodnejší prostriedok, ako dosiahnut' tento ciel'“ (Hobbes 2011, 167). Pre Hobbesa predstavuje najvyšší stupeň autonómie neexistencia vnútorných či externých prekážok. V priestore prirodzeného stavu má každý slobodu na všetko a všetci sú si rovní. Rovnost' však autor nechápe ako rovnakost', ale rovnost' príležitostí - predovšetkým možnosti pripravit' o život druhého v krajnej situácii. Právo na obmedzenie autonómie a slobody človeka možno získat' tromi spôsobmi: 1) Ako právo panovania, získané na základe zmluvy, teda dobrovol'ným prevodom časti autonómie a slobody na suveréna. Týmto prevodom jednotlivec spravidla sleduje zaistenie svojej bezpečnosti a možnosti byt' členom občianskej spoločnosti - štátu. 2) Ako právo panovania na základe vít'azstva vo vojne, ked' sa porazený zaväzuje k poslušnosti vít’azovi výmenou za vlastný život. 3) Spôsob získania moci je narodenie, ked' rodičia prevezmú moc nad diet'at’om.

Po prevzatí moci suverénom sa však autonómia a sloboda jednotlivca výrazne oklieštuje. Prevodom prirodzeného práva na suveréna jednotlivec autonómiu stráca, možnost' jeho slobodného konania závisí od limitov nastavených suverénom. Panovník obmedzuje i slobodu myslenia v rovine in foro externo, čo vyjadruje slovami: „K suverenite patrí tiež posudzovat', ktoré názory a teórie sa mieru priečia a ktoré mu napomáhajú (Hobbes 2011, 215 - 216). Jednotlivec je konfrontovaný so štátnou mocou, ktorej vôl'a predstavuje vôl'u všetkých. Na rozdiel od d’alších dvoch filozofov (Locke, Rousseau), Hobbes striktne spája individualistické zdôvodnenie s legitimitou absolútneho vládcu. „Kým jednotlivci v prirodzenom stave podla Hobbesa majú práva, ale nie povinnosti, poddaným zostávajú po dosadení vládcu povinnosti, ale žiadne práva. (...) Na jednej strane je autor zakladatel' normatívneho individualizmu, na druhej strane vystupuje ako apologét bezpodmienečnej podriadenosti neobmedzenému vládcovi“ (Celikates 2017, 27). Autorov Leviatan - smrtel'ný Boh - je stelesnením absolutistického vládcu, s príchodom ktorého sa končí možnost' neobmedzenej autonómie a do vel'kej miery i slobody jednotlivca. Na druhej strane sa však indivíduum 
týmto procesom zbavuje večnej neslobody spočívajúcej v pocite strachu, ktorý je vždy a všade prítomný v prirodzenom stave. Nezávisle od kontroverznosti záverov autora možno konštatovat', že predmetná teória $\mathrm{v}$ konečnom dôsledku prispela $\mathrm{k}$ diskusii o l'udských právach a slobode. Zmluvné teórie sa stali inšpiráciou pre neskorších liberálnych autorov, pričom ich revidovali v otázkach neobmedzenej moci suveréna a obohatili o garantované slobody občanov.

Pojmy sloboda a autonómia sú v koncepcii J. Locka hlboko prepojené. Podl’a V. Mandu sa viažu najmä na slobodu vierovyznania a právo vlastnit', čo v autorovej filozofii predstavuje jedno a to isté - konkretizáciu slobody a rovnosti človeka v prirodzenom stave (Manda 2013, 237). Na rozdiel od Hobbesa filozof posilňuje autonómiu jednotlivca v spoločnosti, oddel'uje osobnú vieru a presvedčenie od politiky a štátu. „Na rozdiel od hobbesovskej mechanistickej filozofie nadväzuje J. Locke vo svojej politickej filozofii na aristotelovskú tradíciu, ktorá chápe človeka ako sociálnu bytost'. Jej blaho závisí od spoločenstva a od úlohy, ktorú v ňom má“ (Laukötter, Siep 2017, 36). Jednotlivec má povinnost' zachovat' seba a svoju individualitu, je však povinný ochraňovat' aj ostatných jednotlivcov. Autonómia predstavuje v autorovej filozofii samourčenie slobodnej vôle, ku ktorej je človek spôsobilý ako rozumná bytost'. $\mathrm{V}$ prirodzenom stave indivíduum disponuje sebou samým, pričom je podriadené Bohu.

Sloboda a autonómia jednotlivca v prirodzenom stave obsahujú možnost' konat' v mantineloch prirodzeného zákona, avšak narušenie tejto hranice iným jednotlivcom dáva indivíduu možnost' trestat'. Časti svojej slobody a autonómie sa podl'a teórie autora jednotlivci v priestore prirodzeného stavu vzdajú dobrovol'ne, a to prenesením právomoci trestat' na politické spoločenstvo. Tento akt predstavuje isté oklieštenie slobody a autonómie pre indivíduum, avšak tento moment je $\mathrm{v}$ autorovej filozofii rozhodujúci pre dodatočné zosúladenie s právom. „Pretože kde niet zákona, tam nie je sloboda“" (Laukötter, Siep 2017, 37). Fakt, že Locke považuje otázku slobody a autonómie za prioritu, dokladuje aj tým, že k opísanému prenosu časti autonómie a slobody môže dôjst' len so súhlasom všetkých. „Ked’že l'udia sú, ako už bolo povedané, od prirodzenosti slobodní, rovní a nezávislí, nemožno nikoho bez jeho súhlasu zbavit' tohto stavu a podrobit' ho politickej moci“ (Laukötter, Siep 2017, 37). Po takomto súhlase je vláda povinná prenesené práva od jednotlivcov užívat' pre blaho a zachovanie vlastníctva tých, ktorí sa vzdali časti svojej slobody v prospech ustanovenia ustáleného politického spoločenstva. Autori dodávajú, že vlastníctvom sa nemyslí výlučne vlastnenie vecí osobnej spotreby a výrobných prostriedkov, ale i držitel'stvo práva na život, slobodu presvedčenia a konania, telesnú integritu a zákonne nadobudnuté vlastníctvo (Laukötter, Siep 2017, 37). 
Na rozdiel od Locka Rousseau pojmy sloboda a autonómia nespája do jedného pojmu. Za absolútne autonómnych pokladá divochov v prirodzenom stave, ked' si jednotlivec sám určuje zákony, ktoré dobrovol’ne prijíma. V tomto priestore neexistencie súkromného majetku nebol divoch zat’ažený žiadnymi komplexnejšími povinnost'ami, nestála nad ním žiadna vyššia moc. V diele $O$ spoločenskej zmluve sa postavenie l’udí podstatne zmenilo k lepšiemu práve vd’aka spoločnej dohode. Podl'a Rousseaua je to najmä preto, že: „Neistý, krehký spôsob (života) jednotlivci vo vzniknutej spoločnosti podla Rousseaua vymenili za lepší a istejší, prirodzenú nezávislost' (autonómiu) za (občiansku) slobodu, schopnost' škodit' inému za vlastnú bezpečnost' a svoju silu, ktorú iní mohli premôct', za právo, čo sa vd’aka spoločenskému zjednoteniu stáva neporazitel'ným“ (Buraj 2013, 289). I ked' autor svoj postoj k vzniku spoločnosti časom prehodnotil, nezbavil sa obáv z úplnej straty autonómie a prirodzenosti vedúcej $\mathrm{k}$ otroctvu - snaží sa vyhnút' spoločnosti, v ktorej by malo fungovat' právo silnejšieho. Autor pojem práva stotožňuje s morálkou. Človek sa v očiach Rousseaua nesmie zrieknut' svojej slobody a ak spoločnost' nebude sledovat' spoločné dobro, má právo na uplatňovanie občianskej neposlušnosti.

Prirodzená miera autonómie divocha v prvotnom stave, akokol'vek sa ju autor snaží idealizovat', neposkytuje indivíduu potrebnú mieru slobody. Tú ako občiansku slobodu zabezpečuje až spoločnost'. Štát má právo donútit' občana dodržiavat' zákony, čo automaticky neznamená rozpor so slobodou. Naopak, istota, že všetci členovia spoločnosti dodržujú dohodnuté zákony, je garanciou bezpečnosti a férovosti. Ludia sa po uzavretí zmluvy nezriekajú slobody, ale dohodnú sa na istej miere jej obmedzenia. Ako vo svojej analýze píše M. Sobotka: „Jedinec nebol predtým, t. j. v prirodzenom stave, (viac) slobodný, bol len viac autonómny“ (Sobotka 2015, 34). Jednotlivci zmluvou strácajú absolútnu autonómiu, no dosahujú občiansku slobodu v priestore ucelenej spoločnosti riadenej zákonom. Bolo by však nedôsledné označovat' Rousseaua za autora, pre ktorého by sloboda a autonómia jednotlivca nepredstavovali silnú motiváciu. Filozof udáva dve zdôvodnenia pre zachovanie slobody. Prvým argumentom je, že sloboda vychádza z prirodzenosti človeka, druhý argument analyticky vyplýva z koncepcie legitímnej vlády (Brandt 2017, 45). Autonómiu jednotlivca autor zabezpečuje základným právom človeka, a to mu garantuje dôstojnost', ktorá nepozná žiadnu cenu. „Nie je možné, aby l’ud scudzil svoju suverenitu, rovnako ako nie je možné, aby sa človek druhému dal alebo predal (...) je to čin nezákonný“ (Sobotka 2015, 32). Na základe uvedeného možno konštatovat', že autor chápe slobodu v dvoch líniách. Prvou je sloboda - autonómia divocha, ktorý koná sebazákonodarne, bez determinovanosti zvonka. „V negatívnom zmysle je touto slobodou schopnost' vyviazat' sa $\mathrm{z}$ determinovanosti vonkajšieho sveta - konat' na základe zákona rozumu oproti zákonu prírody“ (Blocha 2004, 2). Druhou 
slobodou sa myslí sloboda občianska, získaná po uzatvorení zmluvy. Filozof predkladá koncept, ktorý neskôr rozvinul Kant - spoločenský poriadok nemá byt’ organizovaný prostredníctvom externej sily, ale prostredníctvom samoregulačných princípov praktických dôvodov jednotlivcov. Východiskom druhého prístupu je pre Rousseaua (občianska) sloboda na základe slobodnej vôle. „Tá môže byt' realizovaná len v spoločnosti s druhými, pretože jedinec nadaný slobodnou vôlou je schopný sebaobmedzenia svojho prirodzeného života, (...) ktoré si jednotlivec ukladá s ohl’adom na druhých“ (Sobotka 2015, 34). Napriek tomu, že prítomnost' autority znamená určité obmedzenie autonómie jednotlivca, Rousseau sa jej zastáva, pretože v konečnom dôsledku vedie $\mathrm{k}$ občianskej slobode.

M. Sobotka sumarizuje tento prevod tvrdením, že pri tejto výmene jednotlivec „zamieňa svoju prírodnú (neobmedzenú) autonómiu za život sprevádzaný uznaním druhých ako rovnocenných partnerov v súčinnosti spoločenského života“ (Sobotka 2015, 34).

V autorovej filozofii teda dochádza $\mathrm{k}$ obratu - filozof chápe nevyhnutnost' vzniku spoločnosti, a preto sa snaží o vytvorenie ideálnej verejnej komunity, ktorá by umožňovala ucelený, úplný vývoj a priestor na vyjadrenie autentickej osobnosti napriek existencii autority a obmedzeniu autonómie. Rousseauova koncepcia cieli na kreativitu, l'udskú sebestačnost' a sebarealizáciu. Nepredstavuje koncepciu boja o moc a pozíciu. Rousseauovo hl'adanie autenticity u jednotlivca apeluje na latentný potenciál sebarealizácie, sebavyjadrenia, sebapoznania a sebasmerovania. Jeho ciel'om je predstavit' také spoločenstvo, v ktorom každý jednotlivec môže dat' životu zmysel. Rousseau sa nazdáva, že historický proces bol doteraz príbehom o zotročovaní a biede. Ked’že história predstavuje postupné odbúravanie l'udskej prirodzenosti a zotročovania, adekvátne poznanie pravej podstaty l'udských bytostí nemožno získat' z jednoduchej štúdie minulosti. Pôvodní obyvatelia Zeme sa po krátkom období št’astného a spontánneho života odklonili od jeho pôvodného a pravého účelu a autentickost' sa vytratila. Napriek tomu je autor presvedčený, že je neprípustné identifikovat' l'udskú prirodzenost's akýmkol'vek konkrétnym bodom histórie a verí v prirodzene dobrú povahu človeka (Critchley 2003, 195 - 196).

\section{Záver}

Na príkladoch, ktoré sme analyzovali, možno objasnit' odlišné nazeranie filozofov na pojem vlastníctva, ideálnu podobu usporiadania spoločnosti, indivíduum a jeho slobodu či autonómiu. Pre všetky historické prístupy liberalizmu v rámci anglosas kej politickej filozofie je spoločným znakom dôraz na individualitu a jej jedinečné postavenie v prirodzenom stave, ktoré zohráva rozhodujúcu úlohu pri kreovaní politického spoločenstva. Rozkol v tomto filozofickom priestore tkvie v odlišných 
predstavách o ideálnych formách vlády a o vzt’ahu k súkromnému vlastníctvu, slobode a autonómii.

Pri úvahách o historických zdrojoch liberalizmu treba brat' do úvahy aj odlišnosti názorov nielen medzi jednotlivými prúdmi tejto ideológie, ale aj v rámci samotných diel jej jednotlivých predstavitel'ov. V texte sme sa pokúsili objasnit' niektoré rozdiely medzi autormi, ktorí vychádzajú z rovnakých predpokladov. Kým na idey klasického liberalizmu Locka v modernej filozofii nadväzujú neoliberálne či libertariánske prúdy filozofického myslenia, $\mathrm{k}$ neskorším myšlienkam Milla ${ }^{2}$ či Rousseaua sa prikláňa sociálny liberalizmus, ktorý pripisuje ovel’a relevantnejšiu úlohu štátu v rámci sociálneho systému. Zdá sa, že liberalizmus nie je dogmatická doktrína, z ktorej by sa už nedali čerpat' inšpirácie, pretože nie je ani celkom preskúmaným terénom. Vzhl'adom na d’alší vývoj liberalizmu považujeme za potrebné prehodnotit' analyzované koncepty aj v súčasnosti, pretože rozličné interpretácie kl'účových pojmov našej state rozdel'ujú liberalizmus aj dnes.

\section{Literatúra}

BOLCHA, P. (2004): Kant - Sartre a spät'. Elogos. [online]. Dostupné na: https://nb.vse.cz/kfil/elogos/student/bol104.pdf (Navštívené: 8. 1. 2020).

BRANDT, R. (2017): Jean-Jacques Rousseau. In: Pollman, A. -Lohmann, G. (eds.): Ludské práva Bratislava: Kalligram, $42-48$.

BURAJ, I. (2013): Jean-Jacques Rousseau: zmluva o spoločnosti. In: Novosád, F. - Smreková, D. (eds.): Dejiny sociálneho a politického myslenia. Bratislava: Kalligram, $282-300$.

CELIKATES, R. (2017): Thomas Hobbes. In: Pollman, A. -Lohmann, G. (eds.): Ludské práva. Bratislava: Kalligram, 27 - 30.

CIBÍK, M. (2017): Liberáli a tí druhí. Bratislava: AKA media.

CRITCHLEY, P. (2003): Autonomy, Authenticity and Authority. The Rational freedom of Jean Jacques Rouseau. DOI: http://dx.doi.org/10.17613/M6H98ZC6B

DEWEY, J. (2001): Rekonštrukcia liberalizmu. Bratislava: Kalligram.

HOBBES, T. (2011): Leviatan. Bratislava: Kalligram.

KIS, J. (1997): Současná politická filozofie. Praha: Oikoymenh.

LAUKÖTTER, S., SIEP, L. (2017): John Locke. In: Pollman, A. - Lohmann, G. (eds.): Ludské práva. Bratislava: Kalligram, $34-42$.

LOCKE, J. (1992): Druhé pojednáni o vládè. Praha: Svoboda.

MANDA, V. (2013): John Locke: Vlastníctvo a zmluva. In: Novosád, F. - Smreková, D. (eds.): Dejiny sociálneho a politického myslenia.. Bratislava: Kalligram, 237 - 249.

MANDA, V., SŤAHEL, R., PRUŽINEC, T. (2015): Človek, sloboda a vlastníctvo vo filozofii raného novoveku. Bratislava: IRIS.

MILL, J. S. (2005): Logika liberalizmu. Bratislava: Kalligram.

NOVOSÁD, F. (1993): O slobode a spravodlivosti. Bratislava: Archa.

NOVOSÁD, F., SMREKOVÁ, D. (2013): Dejiny sociálneho a politického myslenia. Bratislava: Kalligram.

POLLMAN, A., LOHMANN, G. (2017): Ludské práva. Bratislava: Kalligram.

\footnotetext{
${ }^{2}$ Predovšetkým z diela Kapitoly o socializme.
} 
ROUSSEAU, J. J. (2010): O pôvode a príčinách nerovnosti medzi l'ud'mi. Bratislava: Vydavatel'stvo spolku slovenských spisovatel'ov.

ROUSSEAU, J. J: (2015): Od „Rozpravy o pôvode nerovnosti“ "ku „Spoločenskej zmluve“. Praha: Karolinum.

RAWLS, J. (2007): Spravodlivost' ako férovost'. Bratislava: Kalligram.

SCHWARZMANTEL, J. (1998): The Age of Ideology. Tavistok - Rochdale: New York Press.

SMITH, A. (2001): Pojednání o podstatě a původu bohatstvi národi̊. Praha: Liberální institut.

SOBOLEWSKA, B.; SOBOLEWSKI, M. (1978): Myśl polityczna XIX. i XX. wieku. Varšava: Państwowe Wydawnictwo Naukowe.

SOBOTKA, M. (2015): Jean-Jacques Rousseau: od „,Rozpravy o původu neovnosti“ ke „Společenské smlouvě “. Praha: Nakladatelství Karolinum.

ŠVEC, J. (2017): Obhajoba vertikálnej redistribúcie prostrednictvom myšlienok liberalizmu: Diplomová práca. Ružomberok FF KU 2017, 46. s.

Stat' vznikla v rámci grantu VEGA 1/0132/17 Právo na nezávislý život osôb s postihnutím a ich začlenenie do spoločnosti z pohl'adu politickej filozofie.

Jakub Švec

Katedra filozofie FF UMB

Tajovského 40

97409 Banská Bystrica

Slovenská Republika

e-mail: jakub.svec@umb.sk

ORCID ID: https://orcid.org/0000-0002-7603-101X 